Jurnal IImiah Iqra'

2541-2108 [Online] 1693-5705 [Print]

Tersedia online di: http://journal.iain-manado.ac.id/index.php/JII

\title{
Supervisi Kepala Sekolah Dalam Meningkatkan Kualitas Kinerja Guru Di Smk Swasta Kota Manado
}

\author{
Abdul Latif Samal \\ Fakultas Tarbiyah dan IImu Keguruan IAIN Manado \\ Latif.samal@iain-manado.ac.id
}

\begin{abstract}
Abstrak
Tujuan dari peneitian ini adalah untuk memperoleh informasi tentang mempengaruh pengawasan utama, iklim kerja sekolah, dan penguasaan materi pelajaran sejarah terhadap kualitas tes buatan guru. Penelitian ini dilakukan di SMK Swasta di Kota Manado yang melibatkan 50 (lima puluh) orang guru sejarah sebagai sampel peneitian ini. Data dikumpulkan dengan menggunakan teknik analisis jalur. Hasil penelitian menunjukkan bahwa: 1) pengawasan utama memiliki pengaruh positif langsung terhadap kualitas tes buatan guru, 2) iklim kerja sekolah memiliki pengaruh positif langsung terhadap kualitas tes buatan guru, 3) penguasaan materi pelajaran (sejarah) memiliki pengaruh positif langsung terhadap kualitas tes buatan guru, 4) pengawasan utama memiliki pengaruh postif langsung terhadap penguasaan materi pelajaran, dan 5) suasana pekerjaan sekolah memiliki pengaruh positif langsung terhadap penguasaan materi pelajaran (sejarah).

Kata Kunci: Supervisi kepala sekolah, Kualitas Kinerja Guru
\end{abstract}

\begin{abstract}
The purpose of this research is to obtain information about influencing the main supervision, school work climate, and mastery of historical subject matter on the quality of teacher-made tests. This research was conducted in Private Vocational Schools in the City of Manado which involved 50 (fifty) history teachers as samples of this study. Data is collected using path analysis techniques. The results showed that: 1) the main supervision had a direct positive influence on the quality of teachermade tests, 2) the school work climate had a direct positive influence on the quality of teacher-made tests, 3) mastery of subject matter (history) had a direct positive influence on the quality of artificial tests teacher, 4) primary supervision has a direct positive influence on mastery of subject matter, and 5) the atmosphere of school work has a direct positive influence on mastery of subject matter (history).
\end{abstract}

Keywords: Supervision of the principal, Teacher Performance Quality 


\section{Pendahuluan}

Evaluasi merupakan salah satu kegiatan penting dalam penyelenggaran pendidikan. Oleh karena itu, kompetensi evaluasi menjadi kemampuan prasyarat yang harus dikuasai oleh setiap guru. Dengan menguasai kompetensi evaluasi, guru akan dapat dan mudah mengontrol tingkat keberhasilan serta penguasaan materi atau kemampuan yang dimiliki peserta didik setelah mengikuti program pembelajaran.

Kualitas hasil evaluasi dalam prakteknya dipengaruhi oleh beberapa hal, antara lain tes yang digunakan. Menurut Anas Sudijono, tes adalah alat untuk mendiagnosis atau mengukur keadaan individu. Keadaan yang dimaksud adalah penguasaan kognitif dan psikomotor seseorang tentang segala sesuatu (Sudijono, 2007). Selain itu, Cangelosi menjelaskan bahwa tes adalah merupakan alat pengukuran terencana yang digunakan guru uuntuk memberikan kesempatan siswa memperlihatkan prestasi mereka dalam kaitannya dengan tujuan yang telah ditentukan (Cangelosi, 1995).

Arifin menggolongkan teknik non-tes dan tes. Teknik non-tes merupakan alat evaluasi untuk mengukur perubahan sikap dan pertumbuhan psikologi sedangkan tes adalah alat evaluasi untuk mengukur keberhasilan pembelajaran (Arifin, 2012).

Hasil yang diperoleh dari evaluasi merupakan bahan pertimbangan untuk perbaikan pendidikan ke depan. Oleh karena itu, guru dalam pelaksanaan evaluasi harus mempertimbangkan hal-hal berikut: 1) kualitas tes yang akan digunakan, dan 2) kemungkinan terjadinya segala sesuatu yang tidak diinginkan dalam penyelenggaraan evaluasi, seperti: kebocoran soal, siswa mencontek, perjokian dan kecurangan-kecurangan yang lain.

Sesungguhpun evaluasi diyakini sebagai hal penting dalam penyelenggaraan pendidikan, kenyataannya justru menunjukan, tes yang digunakan oleh guru adalah tes yang pembuatannya tidak dilaksanakan secara profesional dengan mengikuti prosedur yang disyaratkan. Tidak sedikit guru dalam menyiapkan tesnya dilakukan secara mendadak dengan cara "cut and fil" (gunting dan tempel) dari buku-buku teks, buku kumpulan soal yang tersedia dan dijual bebas. Pada akhirnya, hasil yang diperoleh dari evaluasi menjadi tidak menggambarkan kondisi sebagaimana diharapkan. Tes yang digunakan untuk evaluasii haruslah tes yang berkualitas agar hasil yang diperoleh dari evaluasi menjadi dapat dipertanggungjawabkan. 
Menurut Remmers dan Gage, ciri tes yang berkualitas, yaitu :

1) Valid dan reliabel, 2) mudah dalam pengadministrasian, dan 3) mudah dalam penafsiran hasilnya. Berdasarkan pendapat tersebut, tes yang berkualitas adalah tes yang: 1) valid dalam arti tepat akur dan konsisten hasil yang dicapai, 2) mudah dalam pengadministrasian, mudah dalam hal penggunaanm dan 3) mudah dalam menganalisis, mengartikan dan menginterpretasikan (Remmers \& Gage, 1991).

Tes sebagaimana diuraikan diatas, sudah barang tentu adalah tes yang proses pembuatannya memerlukan waktu, direncanakan secara khusus, dilaksanakan melalui produser yang benar, dibuat oleh tenaga ahli (guru-guru) yang menguasai materi atau substansi dari pelajaran yang akan dibuat tesnya, dan menguasai teknik dalam pembuatan tes yang baik dan benar.

Ada 2 (dua) cara yang biasa digunakan untuk pengujian validitas suatu tes, yaitu: 1) pengujian validitas logika, dan 2) pengujian vadilitas empiris. Menurut Sudijono, vadalitas logika yang dimaksud adalah vadiitas yang diperoleh atas dasar penelaahan dan pemikiran logis. Pengujian validitas logika dapat ditempuh dengan melalui penelusuran terhadap 2 (dua) segi, yaitu: a) dari segi connet atau isinya, dan b) sari segi susunan atau konstruksi (construct) dari tes tersebut (Sudijono, 2007). Berdasarkan pendapat tersebut, yang dimaksud kualitas tes buatan guru (quality ofteacher tes making) dalam penelitian ini adalah kualitas tes yang dibuat sendiri oleh guru yang ditunjukan dengan kadar validitas dan reliabilitas dari tes tersebut.

Terdapat sejumlah kemungkinan yang menjadi penyebab evaluasi tidak dilaksanakan dengan baik dan benar, antara lain: 1) guru tidak memiiki kemampuan yang memadai dalam menyusun tes, 2) guru tidak memiliki pengalaman dalam menyusun tes, 3) guru tidak memiliki waktu untuuk menyusun tes, 4) iklim kerja sekolah kurang kondusif untuk terselenggaranya interaksi edukatif antar seluruh komponen sekolah 5) guru tidak mendapatkan pembinaan yang memadai dari kepala sekolah maupunpengawas, dan 6) guru kurang atau tidak menguasai materi pelajaran yang menjadi tanggungjawabnya.

Supervisi pendidikan (sebagai faktor yang berpengaruh terhadap kualitas buatan guru) menurut Burton, adalah pelayanan bantuan teknis dari para ahli dalam mempelajari dan memperbaiki kerjasama samua faktor yang mempengaruhi perkembangan dan pertumbuhan murid. Supervisi diberikan kepada semua komponen sekolah terutama guru tujuan akhirnya adalah terwujudnya 
perkembangan dan pertumbuhan peserta didik yang optimal (William H. Burton, 1995). Menurut Alfonso, Firth, dan Nevile, pelaksanaan supervisi pengajaran harus secara langsung mempengaruhi guru dalam mengelola proses pembelajaran. Perilaku supervisior harus rinci, terprogram dan berkesinambungan. Tujuan akhir dari supervisi pengajaran adalah guru makin mampu menjadi fasilitator belajar bagi murid-muridnya (Alfonso, Firth, \& Neville, 1981).

Tujuan supervisi bukan hanya berkenaan dengan pengembangan aspek kognitif dan psikomotor saja, melainkan juga menyangkut aspek efektit. Cogan dan Goldhammer seperti dikutip O’Donnell, menggunakan teknik baru dalam supervisi dengan yaitu supersi klinis yang menekankan adanya kerjasama antara supervisior dengan yang disupervisi dalam mencari dan menemukan formula yang paling ideal untuk mewujudkan situasi belajar mengajar yang efektif (O’Donnel, 1995).

Iklim kerja sekolah (sebagai faktor yang berperanguh terhadap kualitas buatan guru) menurut Owen (1991: 167-170) adalah karakteristik lingkungan yang terdiri dari 4 (empat) hal, yaitu: 1) ekologi, bersifat nyata, fisik dan kebendaan dalam organisasi sekolah, 2) lingkungan yang berdimensi sosial seperti: besaran dan variasi gaji guru, tingkat sosial dan ekonomi murid, jenjang pendidikan guru dan lain sebagainya. 3) sistem sosial dan struktur administrasi dalam organisasi, dan 4) kondisi budaya, yang meliputi nilai-nilai, sistem kepercayaan, norma dan pola pikir pegawai dalam organisasi (Owen, 1991). Menurut Davis, elemen-elemen yang berpengaruh terhadap iklim kerja sekolah antara lain adalah: 1) kualitas kepemimpinan, 2) tingkat kepercayaan, 3) komunikasi ke bawah dan ke atas, 4) perasaan berguna tentang pekerjaan, 5) tanggung jawab dari personil yang terlibat, 6) imbalan kerja yang adil, 7) tekanan kerja yang rasional, 8) kesempatan promosi dan karier, 9) kontrol kerja yang logis, dan 10) keterlibatan karyawan dalam ikut berpatisipasi (Davis, 1989).

Uhar Suharsaputra menyatakan bahwa iklim organisasi dapat memberi dampak bagi kinerja organisasi melalui sikap dan perilaku anggota organisasi dalam menjalankan tugasnya. Iklim organisasi yang baik sangatlah penting bagi eksistensi dan kinerja organisasi secara keseluruhan (Suharsaputra, 2010). Menurut Lussier, iklim organisasi mempengaruhi perilaku individu dalam sebuah organsasi (Lussier, 1999). Wirawan menjelaskan bahwa iklim organisasi mempengaruhi sikap dan perilaku organisasi dan kinerja anggota organisasi yang kemudian menentukan kinerja organisasi (Wirawan, 2007). 
Penguasaan materi atau mastery adalah keahlian dalam bidang tertentu atau mengetahui secara mendalam tentang suatu obyek atau kejadian. Barnadib (1997: 12) menyatakan bahwa pengetahuan merupakan materi-materi atau pembendaharaan milik manusia sebagai hasil usahanya untuk mengetahui. Pengetahuan yang dimiliki seseorang tidak datang dengan sendirinya melainkan usaha yang dilakukan (Barnadib, 1997). Bloom dkk, mengelompokkan kemampuan manusia dalam menyimpan pengetahuan menjadi 2 (dua) ranah yaitu: 1) ranah kognitif dan 2) ranah non kognitif. Ranah non kognitif dibedakan pula menjadi 2 (dua) kelompok, yaitu : a) ranah afektif dan b) ranah psikomotorik. Ranah afektif berkaitan dengan nilai-nilai, perasaan dan sikap, sedangkan ranah psikomotor bertalian dengan sensori motorik yaitu; pengendalian otot dalam melakukan gerakan untuk mencapai tujuan tertentu (Bloom \& Dkk, 1956).

Sedangkan sejarah dalam hal ini adalah mata pelajaran sejarah yang dimuat dalam kurikulum dan dijabarkan dalam naskah dan dokumen-dokumen kelengkapannya. Dengan demikian, penguasaan materi pelajaran dalam penelitian ini adaah pengetahuan yang mendalam tentang bahan ajar mata pelajaran sejarah yang dimiliki guru yang meliputi; ranah kognitif, pemahaman, penerapan, analisis, sintesis, dan evaluasi.

Penelitan ini dilaksanakan untuk menguji secara empiris tentang konstribusi atau pengaruh variabel-variabel independen penelitian yaitu variabel $X_{1} X_{2}$ dan $X_{3}$ terhadap variabel dependen $Y$. Penelitian juga dimaksudkan untuk menguji pengaruh varabel indenpenden $\mathrm{X}_{1}$ dan $\mathrm{X}_{2}$ terhadap variabel dependen $\mathrm{X}_{3}$.

\section{Metode Penelitian}

Penelitian ini adalah penelitian survei, mengukur pengaruh supervisi kepala sekolah, iklim kerja sekolah dan penguasaan meteri pelajaran terhadap kualitas tes buatan guru, pengaruh supervisi kepala sekolah dan iklim kerja sekolah terhadap penguasaan materi pelajaran. Penelitian dilaksanakan pada Sekolah Swasta di Kota Manado.

Data penelitian dikumpulkan dengan menggunakan kuesionner dan tes bagi responden guru-guru SMA Swasta di Manado. Adapun metode penelitian yang digunakan adalah metode survei kausal yang bersifat menjelaskan hubungan dengan menggunakan teknik analisis jalur (path analysis). 
Variabel-variabel penelitian terdiri: supervisi kepala sekolah (X1), iklim kerja sekolah (X2), penguasaan materi pelajaran sejarah (X3), dan Kualitas tes buatan guru (Y). Variabel $\mathrm{X}_{1} \mathrm{X}_{2}$ dan $\mathrm{X}_{3}$ adalah variabel-variabel bebas, yang mempunyai hubungan dengan variabel $Y$. Variabel $X_{1}$ dan Variabel $X_{2}$ juga mempunyai hubungan langsung dengan $\mathrm{X} 3$.

Populasi penelitian adalah guru-guru mata pelajaran sejarah pada SMA Swasta di Kota Manado, dengan menggunakan teknik sampling acak sederhana. Besarnya sampel peneltian ini ditetapkan sebesar 20\% dari populasi, yaitu 50 (lima puluh) orang guru SMA mata pelajaran sejarah.

Pengumpulan data supervisi kepala sekolah, dan iklim kerja sekolah dilakukan dengan menggunakan instrumen berupa kuesioner dengan skala Likert. Pengumpulan data penguasaan materi pelajaran sejarah dilakukan dengan menggunakan instrumen berupa tes mata pelajaran sejarah. Sedangkan untuk data kualitas tes buatan guru dilakukan dengan cara rating atau penilaian terhadap tes yang dibuat oleh guru.

\section{Hasil Penelitian}

Data hasil peneltian terlebih dulu dilakukan uji kelayakan persyaratan analisis dengan menggunakan teknik uji normalitas dan uji linieritas. Kesimpulan hasil pengujian adalah data penelitian dinyatakan memenuhi syarat-syarat secara statistik (normal dan linier) untuk dilakukan pengujian hipotesis.

Ringkasan hasil pengujian hipotesis menggunakan teknik analisis jalur dengan bantuan program LISREL 8.72 ditampilkan pada tabel 1 .

Tabel 1. Ringkasan Hasil Perhitungan Koefisien Jalur dan thitung

\begin{tabular}{|c|c|c|c|c|c|c|}
\hline \multicolumn{7}{|c|}{ Koefisien Jalur $(\beta)$} \\
\hline \multirow[t]{2}{*}{ No } & \multirow[t]{2}{*}{ Variabel } & & & 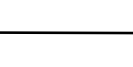 & \multicolumn{2}{|c|}{ Keputusan Kesimpulan } \\
\hline & & SLF* & thitung & ttabel & & \\
\hline 1 & $\mathrm{Y}$ atas $\mathrm{X} 1$ & 0,47 & 4,56 & 2,013 & Ho ditolak & Signifikan \\
\hline 2 & $\mathrm{Y}$ atas $\mathrm{X}_{2}$ & 0,28 & 2,73 & 2,013 & Ho ditolak & Signifikan \\
\hline 3 & $\mathrm{Y}$ atas $\mathrm{X}_{3}$ & 0,24 & 2,24 & 2,013 & Ho ditolak & Signifikan \\
\hline 4 & $\mathrm{X}_{3}$ atas $\mathrm{X}_{1}$ & 0,38 & 2,99 & 2,012 & Ho ditolak & Signifikan \\
\hline 5 & $\mathrm{X}_{3}$ atas $\mathrm{X}_{2}$ & 0,41 & 3,20 & 2,012 & Ho ditolak & Signifikan \\
\hline
\end{tabular}


- $\quad$ Standardized Loading Factor

Model Stuktur 1

Hasil pengujian koefisien jalur sesuai tampilan pada gambar 1. Model analisis koefisien jalur struktur 1 dinyatakan dalam persamaan sebagai berikut :

$$
X_{3}=\beta_{31} X_{1}+\beta_{32} X_{1}+\varepsilon_{1}
$$

Pengujian koefisien jalur sesuai model struktur 1 memberikan penjelasan dan keputusan untuk uji hipotesis adanya pengaruh variabel $X_{1}$ dan $X_{2}$ terhadap $X_{3}$. Dari hasil perhitungan analisis jalur seperti data pada model stuktur 1 , diketahui bahwa nilai p31 sebesar 0,38 dengan nilai thitung $=$ 2,99 adalah lebih besar dari kriteria penerimaan ttabel $(0,05: 46)=2,013$. Dan nilai p32 adalah 0,41 dengan nilai thitung $=3,20$ adalah lebih besar dari kriteria penerimaan ttabel $(0,05: 46)=$ 2,013. Dengan demikian hubungan jalur X1 dan X2 terhadap $X_{3}$ adalah signifikan.

Hasil pengujian koefisien jalur lintasan hubungan antara $X_{1}$ terhadap $Y_{1} X_{2}$ terhadap $\mathrm{Y}$, dan $\mathrm{X}_{3}$ terhadap $\mathrm{Y}$ adalah sesuai tampilan model stuktur 2. Model analisis koefisien jalur stuktur 2 dinyatakan dalam persamaan sebagai berikut: $Y=\beta y_{1} X_{1}+\beta_{2} X_{2}+\beta y_{3} X_{3}+\varepsilon_{2}$

Pengujian koefisien jalur sesuai model struktur 2 di atas memberikan penjelasan dan keputusan untuk uji hipotesis adanya pengaruh variabel $X_{1} X_{2}$ dan $X_{3}$ terhadap Y. Dari hasil perhitungan seperti data pada model struktur 2, diketahui nilai py1 adakah 0,47 dengan nilai thitung $=4,65$ adalah lebih besar dari kriteria penerimaan ttabel $(0,05: 47)=2,012$. Dan nilai py2 sebesar 0,28 dengan nilai thitung = 2,73 adalah lebih besar dari kriteria penerimaan ttabel $(0,05: 47)=2,012$. Dan nilai py3 adalah 0,24 dengan nilai thitung $=2,30$ adalah lebih besar dari kriteria penerimaan ttabel $(0,05: 47)=2,012$. Dengan demikian hubungan jalur $X_{1} X_{2}$ dan $X_{3}$ terhadap $Y$ adalah signifikan.

Data hasil peneltian terlebih dulu dilakukan uji kelayakan persyaratan analisis dengan menggunakan teknik uji normalitas dan uji linieritas. Kesimpulan hasil pengujian adalah data penelitian dinyatakan memenuhi syarat-syarat secara statistik (normal dan linier) untuk dilakukan pengujian hipotesis.

Ringkasan hasil pengujian hipotesis menggunakan teknik analisis jalur dengan bantuan program LISREL 8.72 ditampilkan pada tabel 1.

Tabel 1. Ringkasan Hasil Perhitungan Koefisien Jalur dan thitung Koefisien Jalur (B) 


\begin{tabular}{|c|c|c|c|c|c|c|}
\hline \multirow[t]{2}{*}{ No } & \multirow[t]{2}{*}{ Variabel } & \multirow[b]{2}{*}{$S L F^{*}$} & \multirow[b]{2}{*}{ thitung } & \multirow[b]{2}{*}{ ttabel } & \multicolumn{2}{|c|}{ Kesimpulan } \\
\hline & & & & & & \\
\hline 1 & $Y$ atas $X_{1}$ & 0,47 & 4,56 & 2,013 & Ho ditolak & Signifikan \\
\hline 2 & $Y$ atas $X 2$ & 0,28 & 2,73 & 2,013 & Ho ditolak & Signifikan \\
\hline 3 & $Y$ atas $X_{3}$ & 0,24 & 2,24 & 2,013 & Ho ditolak & Signifikan \\
\hline 4 & $X_{3}$ atas $X_{1}$ & 0,38 & 2,99 & 2,012 & Ho ditolak & Signifikan \\
\hline 5 & $X_{3}$ atas $X_{2}$ & 0,41 & 3,20 & 2,012 & Ho ditolak & Signifikan \\
\hline
\end{tabular}

- Standardized Loading Factor

\section{Model Stuktur 1}

Hasil pengujian koefisien jalur sesuai tampilan pada gambar 1. Model analisis koefisien jalur struktur 1 dinyatakan dalam persamaan sebagai berikut :

$$
X_{3}=B_{31} X_{1}+b_{32} X_{1}+\varepsilon_{1}
$$

Pengujian koefisien jalur sesuai model struktur 1 memberikan penjelasan dan keputusan untuk uji hipotesis adanya pengaruh variabel $X_{1}$ dan $X_{2}$ terhadap X3. Dari hasil perhitungan analisis jalur seperti data pada model stuktur 1, diketahui bahwa nilai p31 sebesar 0,38 dengan nilai thitung $=2,99$ adalah lebih besar dari kriteria penerimaan ttabel $(0,05: 46)=2,013$. Dan nilai p32 adalah 0,41 dengan nilai thitung $=3,20$ adalah lebih besar dari kriteria penerimaan ttabel $(0,05: 46)=2,013$. Dengan demikian hubungan jalur X1 dan X2 terhadap $X_{3}$ adalah signifikan.

Hasil pengujian koefisien jalur lintasan hubungan antara $X_{1}$ terhadap $Y_{1} X_{2}$ terhadap $Y$, dan $X_{3}$ terhadap $Y$ adalah sesuai tampilan model stuktur 2. Model analisis koefisien jalur stuktur 2 dinyatakan dalam persamaan sebagai berikut: $Y=B y 1 X 1+$ $\mathrm{by}_{2} \mathrm{X}_{2}+\mathrm{by}_{3} \mathrm{X}_{3}+\mathcal{E}_{2}$

Pengujian koefisien jalur sesuai model struktur 2 di atas memberikan penjelasan dan keputusan untuk uji hipotesis adanya pengaruh variabel $\mathrm{X}_{1} \mathrm{X}_{2}$ dan $\mathrm{X}_{3}$ terhadap Y. Dari hasil perhitungan seperti data pada model struktur 2, diketahui nilai py1 adakah 0,47 dengan nilai thitung $=4,65$ adalah lebih besar dari kriteria penerimaan ttabel $(0,05: 47)=2,012$. Dan nilai py2 sebesar 0,28 dengan nilai thitung $=2,73$ adalah lebih besar dari kriteria penerimaan ttabel $(0,05: 47)=2,012$. Dan nilai py3 adalah 0,24 dengan nilai thitung $=2,30$ adalah lebih besar dari kriteria penerimaan ttabel $(0,05: 47)=2,012$. Dengan demikian hubungan jalur $X_{1} X_{2}$ dan $X_{3}$ terhadap $\mathrm{Y}$ adalah signifikan. 


\section{Pembahasan}

Hasil perhitungan analisis jalur seperti pada gambar 3 diatas membuktikan bahwa variabel-variabel independen penelitian berpengaruh langsung positif atau memberikan konstribusi positif terhadap variabel-variabel independen. Koefisien jalur variabel supervisi kepala sekolah terhadap kualitas tes buatan guru paling besar yaitu py $1=0,47$. Dan setelah dilakukan pengujian dengan uji $t$ pengaru tersebut signifikan dengan nilai thitung $=4,65>\operatorname{ttabel}(0,05: 46)=2,013$. Hasil perhitungan di atas adalah sesuai dengan kajian teoritik yang menyatakan bahwa supervisi pendidikan oleh kepala sekolah dilaksanakan dalam rangka meningkatkan kemampuan profesi para guru yang ada di bawah kepemimpinannya. Termasuk dalam kemampuan yang diharapkan berkembangan atau meningkat melalui pelaksanaan supervisi pendidikan dalam hal ini adalah kemampuan guru dalam membuat tes sebagai alat untuk mengevaluasi keberhasilan pembelajaran yang diselenggarakan.

Hal demikian bermakna bahwa, makin sering, berkualitas dan bersungguh kepala sekolah melaksankan supervisi kepada guru-guru yang ada di bawah kepemimpinanya akan makin besar kemungkinan para guru menjadi meningkat kemampuannya dalam membuat tes untuk mata pelajaran yang menjadi tanggung jawabnya.

Hasil perhitungan sebagaimana ditampilkan pada gambar di atas juga membuktikan bahwa iklim kerja sekolah berpengaruh langsung positif terhadap kualitas tes buatan guru dengan nilai koefisien jalur py $2=0,28$. Dan setelah dilakukan pengujian dengan uji t pengaruh tersebut signifikan dengan nilai thitung = $2,73>\operatorname{ttabel}(0,05: 46)=2,013$. Hasil perhitungan tersebut didukung oleh kajian teoritik bahwa iklim kerja sekolah kondusif memungkin terjadinya interaksi pembelajaran antar semua komponen sekolah. Hal ini berarti bahwa dalam iklim kerja sekolah yang kondusif, proses daling asah, saling asih dan saling asuh sesama guru dalam pelaksanaan tugas profesinya dapat berjalan dengan baik. Dalam kondisi ini yang sangat memnungkinkan kemampuan profesi guru menjadi terdiring meningkat, termasuk dalam hal ini adalah kemampuan guru dalam membuat tes.

Dari hasil peritungan sebagaimana ditampilkan pada gambar tersebut diatas juga membuktikan bahwa penguasaan materi pelajaran berpengaruh langsung positif terhadap kualitas tes buatan guru dengan nilai koefisien jalur py3 $=0,24$. Dan setelah dilakukan pengujian dengan uji t pengaruh tersebut signifkan dengan nilai 
thitung $=2,30>\operatorname{ttabel}(0,05: 46)=2,013$. Hasil perhitungan tersebut adalah sesuai dengan kajian teoritik yan menyatakan bahwa penguasaan guru yang komprehensif dan mendalam terhadap materi pelajaran menjadi modal dasar yang dapat memudahkan bagi guru dalam mengembangkan butir-butir test yang dibuatnya. Itu berarti bahwa guru yang menguasai secara luas dan mendalam terhadap materi pelajaran (sejarah) yang menjadi tanggung jawabnya akan menjadi mudah baginya mentransformasikan menjadi butir-butir tes yang dibuatnya. Pada akhirnyantes yang dibuat oleh guru yang menguasai dengan baik terhadap materi pelajaran adalah tes yang berkualitas baik pula.

Hasil perhitungan sebagaimana ditampilkan pada gambar tersebut di atas juga membuktikan bahwa supervisi kepala sekolah berpengaruh langsung positif terhadap penguasaan materi pelajaran dengan nilai koefisien jalur p31 =0,38. Dan setelah dilakukan pengujian dengan uji t pengaruh tersebut sigifikan nilai thtung = $2,99>$ ttabel $(0,05: 47)=2,012$. Hasil perhitungan tersebut adalah sesuai dengan kajian teoritik bahwa supervisi kepala sekolah dilaksanakan dalam rangka meningkatkan kemampuan profesi para guru yang ada di bawah kepemimpinanya. Termasuk dalam kemampuan yang diharapkan menjadi berkembang dan meningkatkan melalui penyelenggaraan suoervusu oleh kepala sekolah dalam hal ini adalah penguasaan guru terhadap materi pelajaran yang menjadi tanggungjawabnya. Berarti bahwa makin sering dan bersungguh-sungguh kepala sekolah dalam melaksankan supervisi pendidikan, makin besar pula kemungkinan guru menjadi meningkat penguasaanya terhadap materi pelajaran yang menjadi tanggungjawabnya.

Dari hasil perhitungan sebagai ditampilkan pada gambar diatas juga membuktikan bahwa iklim kerja sekolah berpengaruh langsung positif terhadap penguasaan materi pekajaran dengan nilai koefisien jalur p32 =0,41. Dan setelah dilakukan pengujian dengan uji t pengaruh tersebut signifikan dengan nilai thitung kajian teoritik yang menyatakan bahwa iklim kerja sekolah yang kondusif memungkinkan terjadinya interaksi pembelajaran antar semua komponen sekolah. Itu berarti bahwa dalam iklim kerja sekolah yang kondusif, proses saling asah, saling asih dan saling asuh antar sesama guru dalam pelaksanaan tugas profesinya dapat berjalan dengan baik. Dalam kondisi yang demikian sangat memungkinkan kemampuan profesi guru menjadi terdorong meningkat, termasuk dalam hal ini adalah penguasaan guru terhadap materi pelajaran yang menjadi taggung jawabnya. 


\section{Kesimpulan}

Berdasarkan data dan temuan serta hasil analisis dalam penelitian ini, dapat ditarik kesimpulan bahwa semua hipotesis penelitian yang diajukan dalam penlitian ini diterima dan terbukti kebenarannya. Supervisi kepala sekolah berpengaruh langsung positif dan memberikan konstribusi/pengaruh langsung positif paling besar terhadap kualitas tes buatan guru dengan nilai konstribusi py1 $=0,47$. Demikian halnya dengan variabel-variabel indenpenden penelitian yang lain juga memberikan kontribusi terhadap variabel-variabel dependennya. Besarnya koefisien jalur variabel idenpenden tersebut terhadap variabel dependennya masing-masing adalah: iklim kerjada terhadap kualitas tes buatan guru besar 0,28 penguasaan materi pelajaran terhadap kualitas tes buatan guru sebesar 0,24, supervisi kepala sekolah terhadap penguasaan materi pelajaran sebesar 0,38, dan iklim kerja sekolah penguasaan materi pelajaran sebesar 0,41.

\section{Referensi}

Alfonso, R. J., Firth, G. R., \& Neville, R. F. (1981). Instructional Supervision: A Behavour System. Boston: Allyn and Bacon.

Arifin, Z. (2012). Evaluasi Pembelajaran. Bandung: PT Remaja Rosda Karya.

Barnadib, I. (1997). Filsafat Pendidikan; Sistem dan Metode. Yogyakarta: Andi Offset.

Bloom, B. S., \& Dkk. (1956). Taxonomy of Educational Objectives: The Classifivation of Educational Goal. Handbook 1 Cognitive Domain. New York: David Mickay.

Davis, K. (1989). Human Behavior at Work Organizational Behavior. New York Marawhill Service.

Lussier, R. N. (1999). Human Relations in Organizations: A Skill Building Approach. New York: IRWIN.

O’Donnel, J. (1995). For The Cosen Frew: A Guide to Classroom Supervision. Manila: Cacho Publishing House.

Owen, R. G. (1991). Organizational Behavior in Education. Singapura: Allyn and Bacon.

Remmers, H. H., \& Gage, N. L. (1991). Educational Measurement and Evaluation. New York: Harper \& Brothers Publisher.

Sudijono, A. (2007). Pengantar Evaluasi Pendidikan. Jakarta: RajaGrafindo Persada.

Suharsaputra, U. (2010). Administrasi Pendidikan. Bandung: Refika Aditama. 
William H. Burton. (1995). Supervision: A Social Process. Appleton-Century Crofs Inc. Wirawan. (2007). Budaya dan Iklim Organisasi. Jakarta: Salemba Empat. 